\title{
Dianella tenuissima (Hemerocallidaceae), a remarkable new species from the Blue Mountains, New South Wales, Australia
}

\author{
G.W. Carr \\ Ecology Australia Pty Ltd, 88B Station Street, Fairfield, Victoria 3078, Australia \\ Email: gcarr@ecologyaustralia.com.au
}

\begin{abstract}
A highly distinctive, taxonomically isolated new species, Dianella tenuissima G.W.Carr, confined to sandstone cliff habitats in the Blue Mountains of New South Wales, Australia, is described and illustrated. Its reproductive biology, ecology, taxonomic affinities and conservation status are discussed. The species is regarded as Data Deficient according to IUCN conservation-status criteria.
\end{abstract}

\section{Introduction}

As presently understood, the genus Dianella Lam. ex Juss. (Hemerocallidaceae) (Clifford et al. 1998) in Australia contains approximately 48 validly described, currently recognised taxa (Henderson 1987, 1991; Carr \& Horsfall 1995; Carr 2004 unpubl.; Green 1994) of which only a few extend beyond these shores. Henderson (1987) and Carr and Horsfall (1995) indicated that other species remain to be described, the taxonomic status resolved, or the taxonomic rank of others re-evaluated, particularly the varieties of D. caerulea Sims, D. revoluta R.Br., D. longifolia R.Br. and D. pavopennacea R.J.F.Hend., described by Henderson (1987). Approximately 32 extra-Australian taxa are known (Carr 2004 unpubl.). Taxonomic studies by G. Carr and P. Horsfall (unpubl. data) in the field and the herbarium, and utilising our extensive living collections from all Australian states and territories, and some countries in Malesia, indicate that numerous taxa await description. In addition, almost all taxa have been very inadequately circumscribed, causing many problems in nomenclature (e.g. Henderson 1988) and leading to radical 'lumping', notably by Jessop (1979) and to a lesser extent by Henderson (1987). It is now evident that far more taxa exist than currently described in Australia and elsewhere, and that the genus is much more morphologically, anatomically, chemically and perhaps cytologically diverse than hitherto acknowledged. 
In 1996 my attention was drawn to a Dianella species collected from Newnes Plateau in the Blue Mountains, New South Wales, by Robert T. Miller. It was immediately apparent that it was an undescribed species. Subsequent studies of Dianella material held at NSW revealed one collection of the species and I found it to be locally common on cliffs at Wentworth Falls in 1997. In January 2004 fruiting material was observed and collected at Wentworth Falls and at Katoomba Falls. The cultivated plants flowered in September 2004, providing material to enable the new species to be described and illustrated in this paper.

Terminology in the following description follows Henderson $(1987,1991)$ or Clifford et al. (1998), and colour determination of organs in vivo, frequently diagnostic and of great weight in Dianella taxonomy (Carr \& Horsfall 1995) are given according to the 1986 reprint of the Royal Horticultural Society Colour Chart (RHS London, and Flower Council of Holland, Leiden). The dimensions of the leaves are those of fertile shoots on mature plants, and measurements of vegetative and fertile material were made from fresh and wet specimens.

\section{Dianella tenuissima G.W.Carr, sp. nov.}

Species valde distincta, taxonomia sejuncta, in Montibus Caeruleis (NSW) endemica. Planta parva dense caespitosa. Folia linearia angustissima, flavo-virentia, ad $86 \mathrm{~cm}$ longa, 5-7 mm lata. Culmi foliis 2-4; inflorescentia gracillima floribus 3-10, cymulis distantibus floribus1-3. Flores penduli minuti pedicellis capillaribus, cleistogami vel apertione tarda; tepala late elliptica ad suborbicularia cucullata, dilute hinnulea vel dilute malvina, 3.5-4 mm longa, 2.3-4.4. $\mathrm{mm}$ lata; antherae dilute ad saturate violaceae, ovoideo-cuneatae, 0.9-1.5 mm longae; ovarium parvum depresso-globulare, ovula in quoque loculo 5; stylus violaceus, ad $2 \mathrm{~mm}$ longus; filamenta violacea; strumae parvae luteolae; bacca ellipsoidea, ad $10 \mathrm{~mm}$ longa, $7 \mathrm{~mm}$ lata.

Type: New South Wales: Central Tablelands: Wentworth Falls Reserve, Blue Mountains, G.W. Carr 0401-30a and C.P. Gibson, 6 Jan 2004 (holo NSW; iso MEL).

Densely to loosely caespitose perennial herb to c. $50 \mathrm{~cm}$ high and c. $10 \mathrm{~cm}$ wide at base; shoots very slender, touching or up to $\mathrm{c} .2 \mathrm{~cm}$ apart, shoots \pm erect or slightly inclined. Rhizomes very short, slender, to c. $3 \mathrm{~mm}$ in diameter, cortex yellow, cataphylls encircling and embracing rhizome, to c. $20 \mathrm{~mm}$ long. Roots fibrous, very slender, to 1.5 $\mathrm{mm}$ in diameter (Greyed-Orange 163C). Fertile shoots with 2-3(-4) leaves, subtended by 1 -several reduced, sheathing, acuminate (non-laminate) leaves (cataphylls) to 12.5 $\mathrm{cm}$ long $\mathrm{x} 4 \mathrm{~mm}$ wide at base, these dull crimson or reddish-purple (Greyed-Red 181B or paler); lamina of leaves very narrow-linear, lax, very thin, moderately to strongly arcuate, to $86 \mathrm{~cm}$ long $\mathrm{x}(2.5-) 3-4(-5.7) \mathrm{mm}$ wide, long-attenuate, acuminate, longcarinate at apex, hypostomatous; lamina \pm plane or slightly channelled; leaf sheaths \pm fully occluded at the summit, to $4.5 \mathrm{~mm}$ wide each side of midrib, smooth to minutely hispid with dense, colourless, patent, acute, straight to slightly curved trichomes to c. $1 / 20 \mathrm{~mm}$ long on abaxial surface; leaf sheaths and lamina obscurely striate with 8-12 unequal, parallel veins on each side of midrib, which are conspicuously paler than intervening lamina. Margins of leaf sheaths smooth, edges of lamina smooth almost throughout, or with very small, scattered, colourless, strongly antrorse, straight or curved marginal 'teeth' to $0.4 \mathrm{~mm}$ long and up to $10 \mathrm{~mm}$ apart, distally increasing in frequency, most abundant at apex; midrib costate, subactute, similarly armed in distal 1-4 cm with minute cuticular 'teeth' at the apex. Leaf sheath and elongate cataphylls strongly and uniformly marked abaxially deep to pale crimson (Greyed-Red 181B) 

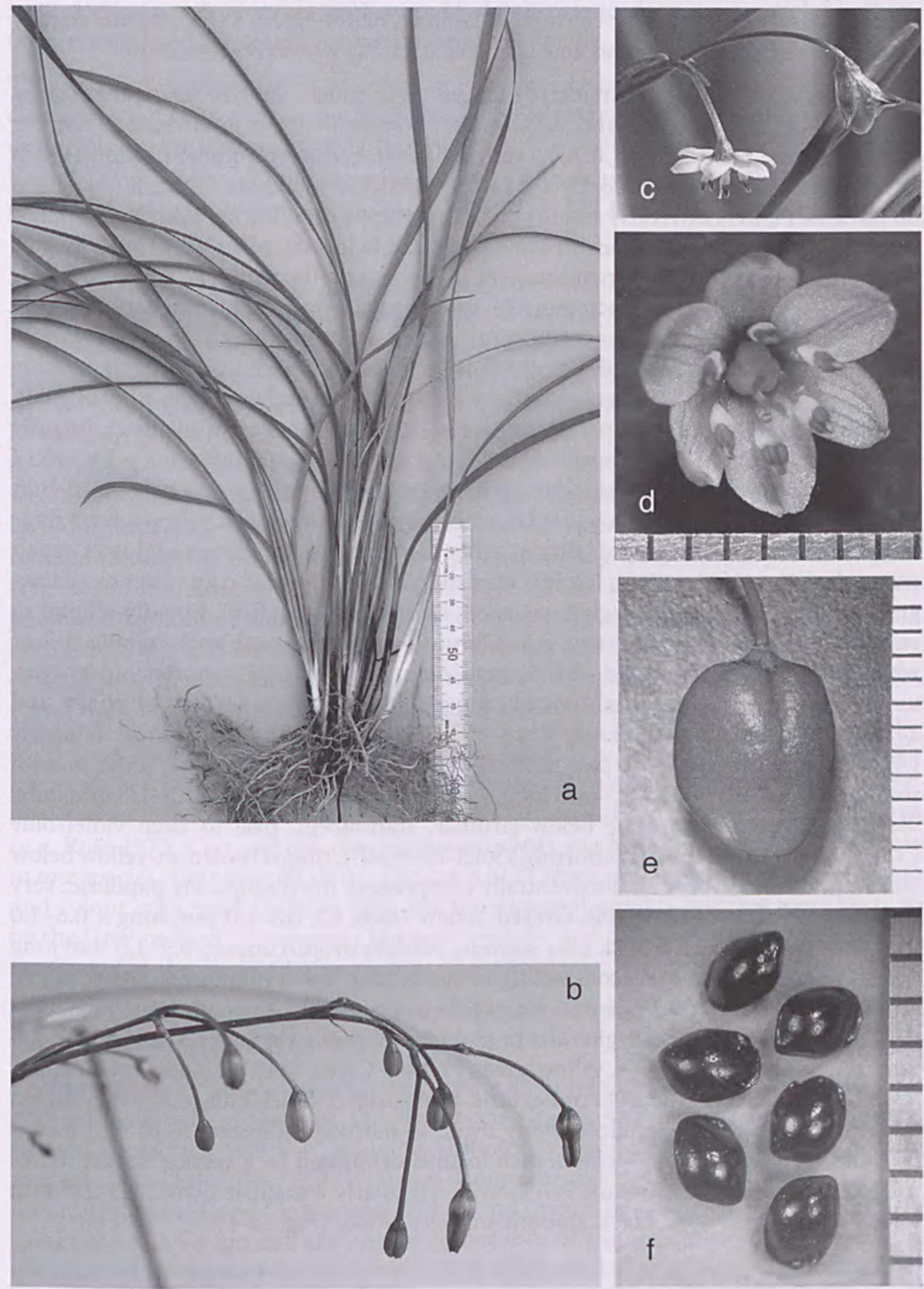

Fig. 1. Dianella tenuissima a, plant from the holotype location in vivo (Carr 0401-30b); b, inflorescence with cleistogamous flowers and developing post-anthesis ovaries (right) (Carr 0401-30); c, flower showing typical opening of perianth and a developing fruit (right) embraced by the hyaline remains of the dead perianth (Carr 0401-30); d, fully opened flower (Carr 040130); e, fruit (Carr 0401-30a); f, seeds (Carr 1401-30a). Scale bar: $\mathrm{a}=\mathrm{cm}$ and $\mathrm{mm}$; d, e and $\mathrm{f}=1$ $\mathrm{mm}$ divisions; $\mathrm{b}$, central cleistogamous flower $4.5 \mathrm{~mm}$ long; $\mathrm{c}$, open flower $8.5 \mathrm{~mm}$ in diameter. 
fading upwards into yellow-green adaxial lamina (Yellow-Green 147A), lamina slightly paler abaxially, faintly glaucous abaxially and adaxially when very immature.

Inflorescence paniculate, extremely reduced and much shorter than the leaves, $10-36 \mathrm{~cm}$ long, interrupted and very slender; flowers 3-10 per inflorescence; scape \pm erect to arcuate, $8-20 \mathrm{~cm}$ long, $0.7-1.0 \mathrm{~mm}$ in diameter, terete throughout, reddish green or reddish brown; cymules (bostryces) 1-3 flowered, racemosely and distantly arranged on the axis. Flowers extremely small, pendant, on terete capilliforme pedicels $8-18 \mathrm{~mm}$ long, the same colour as scape or paler, articulated below the torus, subtended by pale reddish-brown herbaceous-membranous, acute to acuminate, linear, involute bracts the same colour as scape, decreasing in size upwards, from 1-14 mm long. Flowers facultatively cleistogamous (and autogamous) but most opening to allow pollination, 8-9 $\mathrm{mm}$ diameter at full anthesis; floral fragrance not detectable. Tepals remaining tightly to loosely closed, or opening through c. $25-90^{\circ}$ from bud (and then \pm horizontal), subcampanulate to \pm flat; torus prominent. Outer tepals shallowly cucullate, broadly elliptical or rotund, 3.5-4.0 mm long x 2.3-4.4 mm wide, apex subacute with tuft of minute white trichomes; 5 -veined to apex; outer tepals abaxially very pale violet-buff or buff (nearest Greyed-Yellow 161D) with faint to pronounced yellow-green tinge at apex and a tinge of greyed-purple, veins darker reddish-violet; margins of tepals very pale violet (Violet $85 \mathrm{D}$ ); lamina adaxially Violet $85 \mathrm{D}$, veins pale violet or yellowgreen, \pm tinged pale yellow-green at apex. Inner tepals cucullate, broadly-elliptic to sub-orbicular $3.6-4.0 \mathrm{~mm}$ long $\times 2.5-3.8 \mathrm{~mm}$ wide, emarginate with minute tuft of white hairs in sinus; 5 -veined with 3 complete inner veins and 2 shorter outer veins; inner tepals translucent, thinly membranous with crystalline texture, abaxially and adaxially very pale violet (Violet Group $85 \mathrm{D}$, Violet-Blue $92 \mathrm{~A}$ ), much more intensely violet-coloured at base, with pale reddish-violet veins. Stamens 6 , rarely fewer or with some anthers aborted, 3.0-3.5 mm long, \pm erect; filaments subterete, $1.5-1.8 \mathrm{~mm}$ long, markedly sigmoid-geniculate below strumae, translucent, pale to deep violet-blue (Violet Blue 93A at base or uniformly Violet-Blue 94B), tinged brownish-yellow below strumae. Strumae obovoid, dorsiventrally compressed, microscopically papillose; very pale lemon-yellow (Yellow 10B; Greyed-Yellow 160B, C), 0.8-1.0 mm long x 0.6-1.0 $\mathrm{mm}$ wide and c. $0.5 \mathrm{~mm}$ thick near summit. Anthers ovoid-cuneate, $0.9-1.5 \mathrm{~mm}$ long x $0.6-0.8 \mathrm{~mm}$ wide at base, contracting in apical $25 \%$ into a blunt beak, dehiscing by terminal latrorse slits $0.3-0.5 \mathrm{~mm}$ long, pale to deep violet throughout (Violet Blue 92C, 94C). Ovary depressed-globular or globular-ellipsoid, shallowly 3-lobate, 1.2-1.4 $\mathrm{mm}$ long x 1.3-1.6 mm wide, yellow-green (Yellow-Green 144A); ovules 5 per loculus. Style 1.8-2.0 mm long, straight or flexuose, translucent (Violet-Blue 92B, 94C), stigma punctiforme, minutely papillose. Berry ovoid to narrowly ellipsoid, 5-10 mm long x 3-7 mm wide, obscurely 3-lobate, each loculus delineated by a vertical suture, fruits iridescent violet (Violet Group 94A). Seeds irregularly lenticular-ovoid, 2.3-2.5 mm long x 1.6-1.8 mm wide, black, smooth and very glossy. (Fig. 1a-f).

Notes: Dianella tenuissima is remarkable in its habitat, in morphological features and colour of floral organs, and in its reproductive biology. Its taxonomic relationships are obscure and it is taxonomically isolated with no known close relatives. The distinguishing features of this taxon include: the tussock forming habit, narrow leaves to $5.7 \mathrm{~mm}$ wide, the reduced few-flowered inflorescence with 1-3 flowers per cymule, very pale violet perianth and cucullate tepals, violet filaments, very pale yellow strumae and berries that are ovoid to narrowly-ellipsoid and have longitudinal sutures. Other features are uncommon in other species, e.g. the few-leaved fertile shoots (Henderson 
1987, 1991; Carr \& Horsfall 1995, unpubl. data), pale to deep mauve-violet anthers (Green 1994) and the small number of ovules per locule.

The breeding biology of $D$. tenuissima is very unusual. Flowers are facultatively cleistogamous (Fig. 1b), a condition not previously reported in Dianella which is uniformly melittophilous, that is buzz-pollinated by solitary bees (Bernhardt 1995, Duncan et al. 2004, Carr and Horsfall unpubl. data). Apomixis has also been reported once in D. tasmanica Hook.f. sens. lat. (Curtis 1952) but may be much more common (Carr unpubl. data).

Microscopic examination of cleistogamous D. tenuissima flowers from several plants showed dehisced anthers with gaping terminal latrorse slits approximately one third the length of the anther, and numerous pollen grains on the well-developed outer papillae of the stigma. These observations support cleistogamy, rather than apomixis, and it is likely that autogamy is routine, even in flowers that open 'normally' (Fig. 1c). In the early part of the $2-3$ week flowering period in cultivated plants maintained by me (Melbourne) and by Colin Gibson and Robert Miller (Sydney and Bulli), all flowers were cleistogamous and all produced fruit (unless damaged). In the cultivated plants, including the type, maintained by me indoors, flowers opened partially or fully (perianth reflexed through $90^{\circ}$ ) (Fig. 1c) in the mid to late morning yet all flowers produced fruit (Fig. 1e) in the absence of insects, including thrips. It is apparent that flowers open to allow exogamous pollination but that the stigmas have already collected pollen via autogamy in bud. There is no reason to believe that autogamy precludes geitonogamy or xenogamy in individual flowers and there is no morphological evidence to suggest that flowers are not buzz pollinated as typical for Dianella, albeit by small bees.

All flowers examined had five ovules per loculus and the maximum number of seeds recorded per fruit, in the largest examined, was 12. Nothing is known about seed dispersal in D. tenuissima. The genus is routinely and predominantly ornithochorous (e.g. Rose 1973, Carr unpubl. data) and saurochory has been documented in Victoria in one species (Carr unpubl, data). The fruits of D. tenuissima generally conform in size and colour with most Dianella taxa, and the dispersal agent is perhaps most likely to be the Grey or Pied Currawong (Strepera versicolor and S. graculina). Currawongs are implicated in the dispersal of numerous Dianella species (Carr unpubl. data).

Dianella tenuissima occupies an unusual habitat and apparently has unusual habitat fidelity (see Ecology).

Ecology: Dianella tenuissima is known only from Triassic, lithic and quartz sandstone and conglomerate geology of the Narrabeen Group, forming the Blue Mountains Plateau (Bembrick 1980). It occurs at altitudes between c. 800-1200 m ASL where average annual rainfall is 1200-1400 mm (Commonwealth of Australia 1988). It occurs on escarpment cliffs and ledges and pockets and fissures in sandstone rocks, often with minimal soil development, and also in deeper soils of the plateau forest and ravines at the edges of escarpments. Soils are very well-drained, low-nutrient, gradational, finetextured sandy or stony loams, which are often humic, or (in seepage zones) with a high peat content. Plants grow in heavily shaded to very exposed situations of southerly or easterly aspect and soils are \pm permanently moist; the plants often occur in seepage zones. There has been some drought death in recent years and the very thin roots, to $1.5 \mathrm{~mm}$ diameter - the thinnest recorded in Australian Dianella (Carr unpubl. data) probably indicate permanently moist environments and relative drought intolerance in the species. 
Dianella tenuissima occurs in at least two of the vegetation types described and mapped by Keith and Benson (1988) and Benson et al. (1996) for the Blue Mountains: 9i Blue Mountains Sandstone Plateau Forest, and 21c Montane Heath (open heath and cliffs). Associated plant species in Sandstone Plateau Forest include Banksia cunninghamii subsp.cunninghamii', Blechnum wattsii, Callicoma serratifolia, Ceratopetalum apetalum, Cissus hypoglauca, Eucalyptus fastigata, E. mannifera subsp. gullickii, E. oreades, E. piperita subsp. piperita, E. sieberi, Gahnia sieberiana, Hakea dactyloides, H. salicifolia, Lycopodium deuterodensum, Olearia myrsinoides, Persoonia mollis, Pittosporum undulatum, Pteridium esculentum and Stylidium productum.

Associated species in montane heath of cliffs and rock-faces include Acacia obtusifolia, Alania endlicheri, Allocasuarina littoralis, A. nana, Amperea xiphoclada, Banksia cunninghamii subsp. cunninghamii, Callicoma serratifolia, Dracophyllum secundum, Epacris longiflora, E. reclinata, Eucalyptus cunninghamii, E. stricta, Gahnia sieberiana, Gleichenia dicarpa, G. rupestris, Goodenia bellidifolia, G. decurrens, G. rostrivalvis, Hakea dactyloides, Leptospermum polyanthum, L. trinervium, Marsdenia suaveolens, Mitrasacme sp., Patersonia sericea, Pimelea linifolia subsp. linoides, Platysace lanceolata, Smilax glyciphylla, Sprengelia monticola, Stylidium productum, Todea barbara, Tristaniopsis collina, Woollsia pungens and Xanthorrhoea sp.

The species has also been collected in very shaded Ceratopetalum apetalum forest in steep-sided ravines associated with Acacia elata, Blechnum ambiguum, Dracophyllum secundum, Gahnia sieberiana, Lomandra montana, Quintinia sieberi, Sticherus lobatus and Tristaniopsis collina.

Several species of Dianella are sympatric with D. tenuissima at its known locations (Carr unpubl. data): D. tasmanica Hook.f. sens strict., D. sp. aff. caerulea Sims (Blue Mountains), D. sp. aff. caerulea Sims (Katoomba Falls), D. prunina R.J.F.Hend. and D. revoluta R.Br. All of these species are taxonomically distant from D. tenuissima.

Conservation status: IUCN criteria indicate that insufficient information is available and that the conservation status of $D$. tenuissima cannot be adequately evaluated; it therefore remains Data Deficient (IUCN 2001). Given its high-quality habitat and very steep to vertical terrain in an area little modified by human influence, the species is not currently regarded as threatened. There is a need however for further studies to determine its distribution, population status and potential threats.

Etymology: from the superlative of the Latin tenuis, slender, in reference to the exceptionally gracile habit, very narrow leaves and capilliforme scapes and pedicels.

Specimens examined: New South Wales: Central Tablelands: Blackfellows Hand Rock, Newnes Plateau, Blue Mountains, Miller s.n. (Mar 1993) (NSW); Wentworth Falls, Blue Mountains, Coveny 17363 \& Hind, 17 Nov 1996 (NSW).

\section{Acknowledgments}

I am indebted to Colin Gibson (Fairfield, NSW) and Robert Miller (Bulli, NSW) for drawing my attention to this species, for valuable information on its ecology and

1 Taxonomic nomenclature follows Harden (1990-1993) and Harden and Murray (2000). 
behaviour in cultivation, and stimulating discussion. Neville Walsh (MEL) kindly provided the Latin diagnosis and Fig. 1d; Deborah Lau, CSIRO, Melbourne, produced SEM images of leaves; Jamie McMahon, Beverley Mussen, and Carole McWilliam (Ecology Australia Pty Ltd) provided valuable assistance; Lawrie Conole (Ecology Australia Pty Ltd) provided Figs. 1b and 1c. The director of NSW is acknowledged for providing access to collections; editorial comments were kindly provided by Dr Elizabeth Brown.

\section{References}

Bembrick C (1980) Geology of the Blue Mountains, Western Sydney basin. Pp. 134-161 in Herbert C \& Helby R (eds) A guide to the Sydney basin. Geological Survey of New South Wales Bulletin 26. (Department of Mineral Resources: Sydney)

Benson D, Howell J \& McDougall L (1996) Mountain Devil to Mangrove: a guide to natural vegetation in the Hawkesbury-Nepean catchment. (Royal Botanic Gardens: Sydney)

Bernhardt P (1995) The floral ecology of Dianella caerulea var. assera (Phormiaceae). Cunninghamia 4: 9-20.

Carr GW \& Horsfall PH (1995) Studies in Phormiaceae (Liliaceae) 1: New species and combinations in Dianella Lam. ex Juss. Muelleria 8(3): 365-378.

Carr GW (2004) A world checklist of Dianella (Hemerocallidaceae). Unpublished ms. (Ecology Australia Pty Ltd: Fairfield)

Clifford HT, Henderson RJF \& Conran JG (1998) Hemerocallidaceae. Pp. 245-253 in Kubitzki K (ed.) The families and genera of vascular plants: III Flowering plants. Monocotyledons: Lilianae (except Orchidaceae). (Springer-Verlag: Berlin)

Commonwealth of Australia (1988) Climatic averages, Australia, Bureau of Meteorology. (Australian Government Publishing Service: Canberra)

Curtis WM (1952) Variation in certain Tasmanian plants. New Phytologist 51(3): 398-414.

Duncan DH, Nicotra AB \& Cunningham SA (2004) High self-pollen transfer and low fruit set in buzz-pollinated Dianella revoluta (Phormiaceae). Australian Journal of Botany 52: 185-193.

Green PS (1994) Dianella. Pp. 505-506 in Wilson AJG (ed.) Flora of Australia, vol. 49. (Australian Government Publishing Service: Canberra)

Harden GJ (ed.) (1990-1993) Flora of New South Wales, vols 1-4. (New South Wales University Press: Kensington)

Harden GJ \& Murray LJ (2000) Flora of New South Wales, vol. 1 supplement. (New South Wales University Press: Kensington)

Henderson RJF (1987) Dianella. Pp. 194-225 in George AS (ed.) Flora of Australia, vol. 45. (Australian Government Publishing Service: Canberra)

Henderson RJF (1988) Nomenclatural studies in Dianella Lam. ex Juss. (Phormiaceae) 1. Austrobaileya 2(5): 419-426.

Henderson RJF (1991) Studies in Dianella Lam. ex Juss. (Phormiaceae) 2. Austrobaileya 3(3): 473-480.

James TA (ed.) (1994) An assessment of the world heritage values of the Blue Mountains and surrounding plateaus. (Royal Botanic Gardens: Sydney)

IUCN (2001) Red list categories and criteria: version 3.1. (IUCN: Species Survival Commission. IUCN: Gland \& Cambridge)

Jessop JP (1979) Dianella. Pp. 206-209 in van Steenis CGGJ (ed.) Flora Malesiana, vol. 9(1). (Sijthoff \& Noordhoff: Alphen aan den Rijn)

Keith DA \& Benson DH (1988) The natural vegetation of the Katoomba 1:100 000 map sheet. Cunninghamia 2(1): 107-144.

Rose AB (1973) Food of some Australian birds. Еmu 73: 177-183. 


\section{$2 \mathrm{BHL}$ Biodiversity Heritage Library}

Carr, G. W. 2006. "Dianella tenuissima (Hemerocallidaceae), a remarkable new species from the Blue Mountains, New South Wales, Australia." Telopea: Journal of plant systematics 11(3), 300-306. https://doi.org/10.7751/telopea20065731.

View This Item Online: https://www.biodiversitylibrary.org/item/266865

DOI: https://doi.org/10.7751/telopea20065731

Permalink: https://www.biodiversitylibrary.org/partpdf/305741

\section{Holding Institution}

The Royal Botanic Gardens and Domain Trust, New South Wales, Australia

\section{Sponsored by}

Atlas of Living Australia

\section{Copyright \& Reuse}

Copyright Status: In copyright. Digitized with the permission of the rights holder.

Rights Holder: The Royal Botanic Gardens and Domain Trust, New South Wales, Australia License: http://creativecommons.org/licenses/by-nc-sa/4.0/

Rights: http://biodiversitylibrary.org/permissions

This document was created from content at the Biodiversity Heritage Library, the world's largest open access digital library for biodiversity literature and archives. Visit BHL at https://www.biodiversitylibrary.org. 